\title{
Study on the Ability of Athletic Basic Motions (Run, Jump and Throw) of Deaf Students in Payakumbuh
}

\author{
Hendri Neldi*, Asyifa Rahmadhanty ${ }^{2}$ \\ Physical Education \\ Faculty of Sport Science \\ University of Padang \\ 1hendrineldi@ fik.unp.ac.id
}

\begin{abstract}
The problem in this research is the ability to run, jump, and throw Payakumbuh deaf students who were still not going well. So the purpose of this study was to determine the ability of the fundamental motion athletics (running, jumping, and throwing) deaf students Payakumbuh. This type of research is descriptive. The population in this study were Payakumbuh deaf students aged 13-16 years as many as 24 people. The sampling technique used total sampling. Based on the sampling technique, the samples in this study were 24 people, Data athletic ability to run the necessary motion with a test run 30 meters, long jump test jump with no prefix, and toss with the test throwing a ball weighing 0.5 kg. Data were analyzed using percentages. The result showed that 1)Basic motor skills to run 30 meters, $10(41.67 \%)$ the top category, eight people $(33.33 \%)$ medium category, 4 (16.67\%) less category, and $2(8.33 \%)$ less category yet. 2) The ability of the underlying motion jump $2(8.33 \%)$ in both categories once, $4(16.67 \%)$ good category, $13(54.17 \%)$ category is $2(8.33 \%)$ less category, and $3(12,50 \%)$ less category yet. 3) Necessary motion throwing ability, 3 $(12.50 \%)$ both categories once, $2(8.33 \%)$ both categories, 9 $(37.50 \%)$ medium category, and $10(41.67 \%)$ less category.

Keywords-Athletic, fundamental motion, deaf students
\end{abstract}

\section{INTRODUCTION}

Human resources is a potential in enhancing national development. One aspect that is the most influential in the field of education. Education is one measure considers a nation. Indonesia is a nation that is very concerned with education. Every effort made by the government in promoting education. Human resource cooperation is needed to achieve that goal.

In this case the government has set a national educational functions and objectives as stated in Republic Act 20 About the National Education System [1] form

"National Education serves to develop the ability and

nature and civilization dignified nation in the context of the intellectual life of the nation, is aimed at developing students' potentials in order menjadimanusia that faith and fear of God Almighty, noble, healthy, knowledgeable, skilled creative, independent, and become citizens of a democratic and responsible ".
Development of human resources here that became the main object is the next generation. In this life there is also our generation who are born with special needs with a variety of factors. But the limitations of the individual should not make the spirit of education to be receding. Met some schools that facilitate for children with special needs. Even the heathen name megharumkan ysng achievement can be obtained not only in formal education, but also the skills they gain from practice of non-formal and informal education.

Learners with special needs are: "learners are significantly experienced physical, mental, intellectual, emotional, or social, so they require a special nature education. Learners can be taught and students in exceptional schools and school-sekolahbiasa implementing educational system ingkulsi " [2]. Pendidikan for children with special needs are very important because they have a lower level of intelligence in the average normal children. Special needs children require curriculum, teaching staff and infrastructure facilities specially adapted to the type of disability the child.

In the face of the character of the students, then the teachers also must meet both the teacher competency pedagogical, professional, personal and social. So that it can overcome the problems in accordance with the character of the students faced. The impact arising from the disorder that is often experienced various problems in speech and language. Different language skills a child hears the language skills of deaf children. Limitations of every deaf child does not eliminate the right of each anakuntuk get equal opportunity in all aspects of kehidupantermasuk in it an opportunity to get an education. Likewise with deaf children deserve the chance to get an education in common with other hearing children. So with that, Deaf children can also live independently and tidaktergantung with people on sekitarnya.Hambatan hear owned by a deaf child, menyebabkanmereka have limitations in understanding the speech of others when engaging in receiving and delivering heart's content, express ideas or opinions, and deliver the message. So jugadalam learning process, deaf children sometimes experience kesulitandalam understand 
the material presented by the teacher. Children with hearing impairment often experience a lack of understanding the material taught by gurunya.Memahami material presented by the teacher, deaf children akanmemanfaatkan residual hearing and seeing the lip movements of teachers (oral). menyebabkanmereka have limitations in understanding the speech of others when engaging in receiving and delivering heart's content, express ideas or opinions, and deliver the message. So jugadalam learning process, deaf children sometimes experience kesulitandalam understand the material presented by the teacher. Children with hearing impairment often experience a lack of understanding the material taught by teacher. Understanding the material presented by the teacher, deaf children should make use of residual hearing and seeing the lip movements of teachers (oral). Cause them to have limitations in understanding the speech of others when engaging in receiving and delivering heart's content, express ideas or opinions, and deliver the message. So Jugadalam learning process, deaf children sometimes experience difficulties Itandalam understand the material presented by the teacher. Children with hearing impairment often experience a lack of understanding the material taught by teacher. Understanding the material presented by the teacher, deaf children should make use of residual hearing and seeing the lip movements of teachers (oral).

Payakumbuh is one of the cities that provide education for children with special needs. Outstanding educational services in Payakumbuh there are 10 schools (SLB) SLB ie 1 and 9 Private SLB. Each SLB are kindergarten education level, SDLB, SMPLB and SMALB.Mata lessons that will researchers understood better that physical education. Based on observations and interviews investigators with some educators in the school environment that implementation of teaching physical education has not gone up is evidenced still many students who are less active in the learning process of physical education, especially in the material athletic basic motion (running, jumping, throwing), In addition, neither of the teachers have graduated from sarjanapendidikan sport. Maybe that factors that lead to poor achievement of learning goals in adaptive physical education, especially athletics material covering basic motion running, throwing and jumping. Through the development of media in teaching physical education, is expected to add to the attractiveness and motivation of learners in making adaptive physical education learning activities.

"the essence of adaptive learning is a regular instructional modified and designed so that it can be studied, implemented and meet the educational needs teaching children with special needs (ABK)" [3]. Motion activity greatly affect the physical condition of the individual. Moreover, it will help the development of psychological and social aspects. Schools in also learning pendidikanjasmani. Khususpun needs children also require special treatment, so they can feel the motion activity / learning physical education adapted to the character of the students.
Argues adaptive learning for exceptional children are extraordinary education [4]. Special education is designed study aims to respond or meet the needs of children with unique characteristics. Required to implement an adaptive learning competencies and creative educators have the perseverance to provide services and special programs [5].

From the definition above, it can be concluded that physical education adaptive is a series of physical activities designed and tailored specifically for children with special needs who systematically in order to stimulate the growth and development of children and to improve the ability of children in various aspects such as ability, intelligence, positive attitude and character a child with special needs in achieving educational goals.

\section{METHODS}

Type of research is descriptive. The population in this study is a student at the State Special Schools for Deaf aged 13-16 years in Payakumbuh as many as 24 people. This study uses sampling with a total sampling technique or the entire population be subjects in research and engineering subjects taking the census. The research subjects in this study were classified deaf students with age range 13-16 years in Schools in Payakumbuh numbered as many as 24 people. Data collection techniques used in the study is an athletic movement that is the basis of running, jumping and throwing. Data analysis techniques in this study using descriptive data analysis techniques.

\section{RESULTS AND DISCUSSION}

\section{Motion Variable base flee}

Results of basic motion data run of 24 deaf students in Payakumbuh, as measured by the 30 -meter run then found the highest scores were 5.00 and 12.03 and the lowest score is the measurement distance (range) is 7.03 . Then the values obtained average (mean) is 7.19 , the standard deviation is 1.71, and the midpoint (median) is 8.52 . Furthermore, the distribution of basic motion data classification results ran 30 meters deaf students in Payakumbuh can be seen in Table 1 .

Table 1.Distribusi Results Data Basic Motion Running Deaf StudentsPayakumbuh

\begin{tabular}{|c|c|c|c|}
\hline Category & Class Interval & $\begin{array}{c}\text { Frequency } \\
\text { Absolut }\end{array}$ & $\begin{array}{c}\text { Relative } \\
\text { Frequency }\end{array}$ \\
\hline Very well & $<4.63$ & 0 & 0 \\
\hline Well & 4.63 to 6.33 & 10 & 41.67 \\
\hline Moderate & 6.34 to 8.04 & 8 & 33.33 \\
\hline Less & 8.05 to 9.76 & 4 & 16.67 \\
\hline Less than Once & $>9.76$ & 2 & 8.33 \\
\hline \multicolumn{2}{|c|}{ Amount } & 24 & 100 \\
\hline
\end{tabular}

Based on Table 4 above, it can be concluded that out of 24 deaf students in Payakumbuh, which has a basic motion run in both categories was not a single person who has it and for basic motion run good category as many as 
10 people (41.67\%), for the medium category, namely 8 $(33.33 \%)$. Furthermore, who has run the basic motion less category that is there are 4 people $(16.67 \%)$ and less category once there were $2(8.33 \%)$. For more details see in Figure 5 below.

Based on the description of the results of basic motion data run of 24 deaf students in Payakumbuh, then the data obtained by students who have a basic motion run above the average group score is $15(62.50 \%)$, and no one is sure students have basic motion running in the average group score. While deaf students in Payakumbuh who has run the basic motion score below average group score as many as 9 people $(37.50 \%)$.

\section{Variable Basic Motion Jump}

Results of data from 24 deaf students in Payakumbuh, for basic motion variables found to jump the highest score was 219 and the lowest score is 73 and the measurement distance (range) is 1463 . Then the average values obtained (mean) is 152.71 , the standard deviation is 39.83 and the median value (median) is 146. Here is shown the distribution of categories of basic motion data results jump deaf students in Payakumbuh can be seen in table 2 .

Table 2. Distribution of Motion Data Base Jump deaf students in Payakumbuh

\begin{tabular}{|l|c|c|c|}
\hline Category & $\begin{array}{c}\text { Class } \\
\text { Interval }\end{array}$ & $\begin{array}{c}\text { Frequency } \\
\text { Absolut }\end{array}$ & $\begin{array}{c}\text { Relative } \\
\text { Frequency }\end{array}$ \\
\hline Very well & $>212$ & 2 & 8.33 \\
\hline Well & $173-212$ & 4 & 16.67 \\
\hline Moderate & $133-172$ & 13 & 54.17 \\
\hline Less & $93-132$ & 2 & 8.33 \\
\hline Less than Once & $<93$ & 3 & 12.50 \\
\hline \multicolumn{2}{|r|}{ Amount } & 24 & 100 \\
\hline
\end{tabular}

Based on Table 5, it can be concluded that out of 24 deaf students in Payakumbuh, for basic motion variable jump in both categories so there are $2(8.33 \%)$, for both categories, namely there are 4 people $(16,67 \%)$, and for the category of being as many as 13 people (54.17\%). Furthermore, for the category of less that $2(8.33 \%)$ and less category once there were 3 people $(12.50 \%)$. For more details basic motion histogram variable jump deaf students in Payakumbuh see in Figure 6 on the next page.

Based on the description of the results of variable data basic motion jump of 24 deaf students in Payakumbuh, then obtained the data of students who have basic motion down on the group score average is 12 people (50\%), and who have the basic motion jump in the average group score is only one person $(4.17 \%)$. Furthermore, there are as many as 11 people $(45.83 \%)$ Deaf Students in Payakumbuh have basic motion jump below the average group score.

\section{Variable Basic Motion Throw}

The result of the throwing motion data base of 24 deaf students in Payakumbuh, the value of the average (mean) is 8.44 , the standard deviation is 3.57 . Then the highest score for the basic motion variable throw is 18.66 and the lowest score is 3.60 , while the distance measurement (range) that is 15.06 and the median value (median) is
11.13. Furthermore, the distribution of basic motion data results category lemparsiswa deaf in Payakumbuh can be seen in Table 3.

Table 3. Distribution of Basic Motion Data Deaf Students Throw in Payakumbuh

\begin{tabular}{|c|c|c|c|}
\hline Category & Class Interval & $\begin{array}{c}\text { Frequency } \\
\text { Absolut }\end{array}$ & $\begin{array}{c}\text { Relative } \\
\text { frequency }\end{array}$ \\
\hline Very well & $>13.80$ & 3 & 12.50 \\
\hline Well & 10.23 to 13.80 & 2 & 8.33 \\
\hline moderate & 6.66 to 10.22 & 9 & 37.50 \\
\hline Less & 3.09 to 6.65 & 10 & 41.67 \\
\hline Less than Once & $<3.09$ & 0 & 0 \\
\hline \multicolumn{2}{|c|}{ amount } & 24 & 100 \\
\hline
\end{tabular}

Based on Table 6 above, it can be concluded that the deaf students to the basic motion throwing good category once there were 3 people $(12.50 \%)$, for both categories is $2(8.33 \%)$ and for category was that as many as 9 people $(37.50 \%)$. As for deaf students who have a basic motion throwing for less category as many as 10 people $(41.67 \%)$ and for the basic motion throwing at least once a category no one is sure who owns it. For more details can be seen histogram figure 3.

\section{DISCUSSION}

Deaf is someone who is experiencing a shortage or limited ability to hear either in part or in whole or are caused by malfunction in part or in whole or hearing aids. Deaf children usually find it difficult to talk or mute, or can be said to be a shortage of oral language. They are difficult to hear conversations that are weak, talk by hearing, get a hearing difficulty in the regular classroom atmosphere. Even deaf children can not use hearing instruments in everyday life which have an impact on life in the complex.

Although deaf children have difficulty mendengan and communicate with others, but they still can be educated well in school (SLB) using hearing aids and in learning to use sign language, lip, spelling finger, gestures or gesture. But they have the same rights to education, learning diataranya adaptive physical education.

"the essence of adaptive learning is a regular instructional modified and designed so that it can be studied, implemented and meet the needs of Exceptional Children learning education (children with special needs)" [3]. Based on the results of research on the basic motion measured with a test run run 30 meters, it was found that no one is likely to have a very good category, and there are 10 students have the basic motion run either category. Then as many as 8 people deaf students have run the basic motion medium category, and 5 categories less, and no two students have the basic motion run less category yet.

The results of the study in accordance with the analysis of data on basic motor skills jump deaf students in Payakumbuh as measured by the long jump without prefix, of 24 people, then there are 2 students have basic movement abilities jump in both categories once and 4 categories. As for the category of being there as much as 
13 orang.Selanjutnya for less category 2 and category ie less once there were 3 people. Thus we can say that the basic motor skills jump deaf students in Payakumbuh most have a medium category.

Of 24 deaf students in Payakumbuh on the ability of the throwing motion, it was found 3 people have excellent category, both categories 2 and 9 the medium category, and as many as 10 people had a throwing motion capabilities at less category. In accordance with the findings of these results it is clear that there are many deaf students do not yet have the ability to throw the ball well. This may be caused by many factors, which are caused by keterbatas deaf children who are physically have a deficiency or physical limitations like other normal children.

\section{CONCLUSION}

1. Basic motor skills to run 30 meters, from 24 deaf students, $10(41.67 \%)$ the good category, 8 people $(33.33 \%)$ medium category, $4(16.67 \%)$ less category and $2(8.33 \%)$ less all categories

2. Basic motor skills jump of 24 deaf students $2(8.33 \%)$ both categories once, $4(16.67 \%)$ good category, 13 $(54.17 \%)$ category is, $2(8.33 \%)$ less category and 3 $(12,50 \%)$ less category yet.

3. Basic motion throwing the throwing ability of 24 deaf students, $3(12.50 \%)$ both categories once, $2(8.33 \%)$ both categories, $9(37.50 \%)$ sedangdan category 10 $(41.67 \%)$ less category.

\section{REFERENCES}

[1] Ministry of National Education. Anka Educational Services Guidelines For Autistic Children. Jakarta: Ministry of Education. 2003.pp.23-43

[2] Hadith. "Autistic Children with Special Needs Education". Bandung: Alphabet. 2006. pp.50-58

[3] Hosni. "Adaptive pembelajran Biasa". JakartaTo Schools: MONE. 2003.pp.12-32

[4] Erianti. "Adaptive Physical Education.Poor".Wineka media. 2011.pp. 10-24

[5] Erianti and D. Novita Sari "Learning Media Development PenjasAdaptifdi SLB Negeri 2 Padang" .Nikken. Padang State University. 2018.pp.12-43 